\title{
STUDY OF TAOISM ETHICS AND ITS IMPLEMENTATION FOR DEMOCRATIC COMMUNITY DEVELOPMENT IN INDONESIA
}

\author{
Iriyanto Widisuseno \\ Program Studi Bahasa Jepang, Fakultas Ilmu Budaya, Universitas Diponegoro \\ Semarang, Jawa Tengah - Indonesia \\ E-mail: widisusenoiriyanto@yahoo.co.id
}

\begin{abstract}
Civil society mobility influences the need for law enforcement and respect for moral values. The study of Taoist ethics becomes important to explore ethical ways of life in accordance with natural law. Civilized democracy must be based on Taosme's ethical values, purity of heart, sincerity, justice and dedication of civilized democracy must be based on Taosme's ethical values, purity of heart, sincerity and devotion. This study tries to reveal basic things which mean the importance of Taoist ethical teachings naturally; (b) Revealing the basic problems that arise in the empowerment of democratic societies against civil society in Indonesia; (c) Find philosophical views about values that are relevant and contribute to the empowerment of democratic societies towards civil society in Indonesia. The method of analysis uses: hermeneutic descriptions, heuristics and synthesis. To achieve the objectives of the first research, using the method of hermeneutic description, to express the fundamental meanings that give significance to Taoist ethical teachings. The purpose of the second research is using the heuristic approach, a step to find ways to solve problems scientifically. The road to science, through explorative understanding of the meaning of concepts or texts, to get a specification of the fundamental problems that arise in the empowerment of democratic civil society in Indonesia. To achieve the third research objective, using a synthesis approach, which is combined exclusively by drawing vertices of logical and contextual relevance. The results show that universal ethical values in Taoist natural ethics such as simplicity, honesty, discipline, compassion, obedience, sincerity, justice, have meaning and relevance to the basic issue of plurality of civil society's life towards democratic society in Indonesia.
\end{abstract}

Keywords: Democratic society; Taoist ethics; symbolic ethic, Indonesia

\section{Introduction}

The reform movement in Indonesia which initially had a noble purpose is now increasingly blurred, namely the loss of its base and direction, in the process is increasingly out of control of norms of democratic ethics. The emerging themes of democracy and human rights only manifest the attitude and actions of anarchism and brutality in society. Differences and disagreements, until the dispute between political elites is not the point of convergence that leads to the solution of common problems, but rather sharpen the spirit of the interests of primordialism rather than the interests of the nation, in the end only fighting over the rights and powers that can loosen the cord glue of unity and national unity.

In addition, the crisis of human values as a result of the development of science and technology. The development of science and 
technology today often forget the human factor. Humans now have to adjust to technology, now humans seemed imprisoned by the grid technology. Such knowledge and technology necessarily confronts humanity on its humanitarian problems, even human beings enter inhumane processes of life. The influence of science and technology not only leads to symptoms of dehumanization, such as the suppression of human values by the current development of the rationalization of human culture, but also touched the vital role of people's lives and in turn can change human culture. Another thing that is not less important, that the Indonesian nation is currently entering a period of transition, from the bureaucratic system of power toward the period of the populist system. In this period of transition, there is a process of democratization of civil society that demands freedom, openness and space for the participation of all members of society through themes of democratic struggle and human rights. Responding to the development of Indonesian society today need to uncover and learn from Taoism natural ethics. Taoism as one of the great schools of philosophy in China has contributed much to the thought of natural ethics, which teaches the ethical life experience in accordance with the laws of nature, its whole teaching is packaged into the theory of virtue (te).

According to Taoism, to do virtue means one has done wu-wei, ie not doing things that are contrary to the laws of nature, maintaining the balance of life, holding on to nature's nature, and living in fairness. By doing virtue one has moral power, because man can live together and live his neighbor on the basis of pure heart (sincerity). Obedience to the laws of nature can acquire knowledge of ethical life values, namely fairness, sincerity, discipline and obedience. Another thing can be obtained from the law of nature is the principle of life balance. This life-balance principle teaches people to avoid the egoism of interest, for that man must learn to be appreciative and willing to accept the reality in his life (Lim Tji Kay, 1991 : 22). Then life according to natural traits can be found in Taoist philosophy, that every human being has his own natural nature, for it and everything has its way. The path of each individual is his nature, his custom of developmental law, man must accept all the facts within himself. This kind of awareness of life can foster a mental attitude and a positive way of thinking, and whatever happens in life can receive and utilize it well. Living naturally, it can be found in Tao's reversal law, ie if people act excessively then the results obtained are the opposite. Therefore, if people want to achieve high achievement people should act fair. This way of life teaches people to keep pseudo life, way of life out of their own ability and must be honest. The wise who know the Tao know how humans should conform to nature. Such a life will be calm, happy, not thinking about the longevity, life and death are the same because human life comes from Tao, then back to Tao. Life is not for oneself but for the good and the salvation of others. Such a way of life can foster a calm, social soul and train the sharpness of reflecting on a higher and transcendent world. The Taoist virtue principle is life is not harmful, keeps the survival together, aims to achieve the happiness of life. The greatness of Taoist philosophy is certainly not without weakness, or lack, but in terms of advantages or positives which among other ethical teachings put forward the principle of 
peace and harmony for the life of society and the state is still relevant serve as the foundation of orientation, criticism and evaluation for the determination of policy empowerment Democratic society to civil society in Indonesia. Given that complex problems will arise, especially problems related to the need for democratic ethical rules. As it is known that the substance of civil society is a democratic society that has a number of characters that demand the need to appreciate the values of moral-ethics, so that important themes are scheduled such as the theme of freedom, independence, political participation and so on. Can be achieved through a process of civic democracy.

Research on Taoism has indeed been done a lot, but this research is different from previous research or scientific work. Previous research of scholarly work in general examines the history and development of Taoism. Then the research results Deng Ming Dao in the publication of Everyday Tao (1966), this study examines the symbolic meaning in natural phenomena. Another study conducted by Imam Wahyudi, (2008), examines the epistemological problems in Taoism.This research will examine Taoism's fundamental thoughts of virtue, and some of the essentials of that theory of virtue. Can be drawn as a contribution to the empowerment of democratic society towards civil society in Indonesia.This study of the doctrine of virtue concerns the knowledge of the recognition of life according to the laws of nature, natural law, and life naturally. Then conduct critical and elaborative eclective evaluations to acquire relevant philosophical and controversial aspects.

The basic laying of Tois is Yang Chu. In the subsequent developments of Taoism popularized by Lao Tzu, to the Chinese literary tradition, Lao Tzu was the founder of the Taoist school. The first disciple of Lao Tzu and who continued his teachings was Chuang Tze. Chinese literature recognizes Taoism's name as philosophy and Taoism as a religion. Each has different teachings. Taoism as a philosophy or Tao Chia teaches that people live according to the laws of nature, whereas Taoism as a religion or Tao Chiao teaches that people are opposed to the laws of nature. In the history of its development, the two did not clash. Because the meaning of religion and philosophy in China does not have a clear barrier in the practice of everyday life (Fung Yu Lan, 1990 : 3-43).

Furthermore, this study will examine the important matters of Taoist philosophy that can contribute to the empowerment of democratic societies to civil society in Indonesia. The relevance of Taoism is contained in the Taoist doctrine of the interpretation of natural law, natural law and the simplicity of life as an orientation of empowering the mental attitude and morality of Taoist society. Virtue (te) is something that taoists want to address. Te is the fruit or result obtained by a person when running Tao (Kwee Tek Hoaij, 1935: 454). To achieve virtue one must do according to the Tao's way. The way of life of Tao is the virtue itself, as Lao Tzu states that the quality of one's virtue is found in the way of life. Wing Tsit Chan (1963) affirms that living conforming to Tao is virtue itself, as in his statement: The all embracing quality of the great virtue of Tao. If in ones life follows Tao, that is virtue indeed (Wing Tsit Chan, 1963: 125). Then in the preface Deng Ming Dao also explains, as follows. Following Tao means following a living path. It is a way of life that sustains you, guides you, and leads you to innumerable rich experiences. It is a spiritual path of joy on insight (Deng Ming Dao, 1996:ii). 
How is the way of life referred to as the way of the Tao? In the symbolism of the Tao is likened to water, a person has great moral power and noble personality like water. Water always benefits all things, but does not seek service. Water is always humble despite always benefiting all life. This is the picture of the life of the wise person. The teachings of Taoism are somewhat elusive, because it is not systematic, in the form of poems and symbolic. To understand it must approach hermeneutics and elaborative reflection on the concepts or text of symbolic philosophy and mengkomprehensikan into the form of a whole and systematic concept. Factors ability to interpret and is needed here, namely to reveal the meaning of symbolic thinking in philosophy. Symbolism in Taoist philosophy emphasizes ethics rather than metaphysics and religion, so it is often called ethical symbolism. As Wing Tsit Chan states: The emphasis of the symbolism of Tao is ethical rather than metaphysical or religious (Wing Tsit Chan, 1963:7).

The ethical symbolism in the Taoist philosophy is a reflection of the natural human idealism that everyone should have, as the implication that man must act in accordance with the laws of nature. Ethical symbolism has a meaning for humans, that human beings become wise if able to translate or interpret and describe the laws of nature and transform it into everyday attitude and deeds based on original purity and simplicity of life. This pattern of human life in its cumulation will create a harmonious and prosperous society. This Taoime concept of virtue can substantially contribute to the life of today's society. Especially for the people of Indonesia who are building democratic life in all fields through the empowerment of civil society, then the ethics of democracy that comes from the value of virtue is needed. As a concept, the terminology of civil society derives from the historical process of western society. The development of his thought was initiated by Cicero, but according to Manfred Riedel this concept is known since Aristotle. (AS Hikam, Muhammad, 1996: 2).

Civil society at the beginning of its development has been radically understood by political thinkers, by emphasizing the independence and differentiation of its position, thus becoming the antithesis of the state. This view was opposed by Hegel. He proposed the theory that civil society can not be left without control but needs rules and unification with the state. Hegel's view is sociological and ignores the independence that becomes the core. Hegel saw the position of the state as the last measure and the owner of a universal idea. Hegel's views are criticized by modern thinkers, such as Robert Mohl, J.S. Mill, and Alexis de Tocqueville who want to restore the dimension of independence and plurality in civil society. The realization of plurality, independence, and political capacity, then citizens will be able to balance and control the strength of the state. The development of civil society and its consolidation has always been oriented towards the process of formulating the democracy of modern society. Democracy is not only determined by formal procedures, laws and legislation, but by the acceptance of substantive and controlling powers from social movements and social associations that are engaged as political or non-governmental organizations. The association is a civil society actor. In other words, civil society can not be understood merely as an object such as a nation and nation, but as part of a social 
process that is driven by the flow of lower society in an organized manner (Jenny Pearce, 1997: 159)

As the basis and direction of the course of research can be formulated problem, that is as follows. The things that underlie Taoism's natural ethical teachings about virtue (te) are important. What issues arise in the empowerment of democratic societies towards civil society. What is the form of the natural ethical teachings of Taoism that can be contributed to the empowerment of a democratic society into a civil society. There are several goals to be achieved in this research, which is as follows. (a) Revealing the basic things that mean the importance of the ethical teachings of natural Taoism; (b) Revealing the basic issues that arise in the empowerment of democratic societies towards civil society in Indonesia; (c) Finding a philosophical view of the relevant and contributive virtues for the empowerment of democratic societies towards civil society in Indonesia.

\section{Research Method}

This research includes the type of qualitative research. All research data obtained through literature and documentary studies on Taoism and Civil Society treatises. The material object of this research is the philosophical thought of Taoism, especially the natural ethical doctrine of virtue. The formal object of his research, is the natural ethics of Taoism. The way the research is adapted to the nature of the science of philosophy, that is placing the objects of the target as a whole and thorough. Materials or research data include the main ingredients of research and secondary research materials. The main ingredients of the study were taken from the primary literature, ie books by Taoist figures such as: (1) Lao Tzu (1985), Tao Te Ching The Book of Meaning and Life; (2) Chuang Tzu (1973), Taoist
Philosophy and Chinese Mystic; (3) Deng Ming Dao (1965), Everyday Tao. Other research materials are secondary materials of research taken from secondary literature, in the form of works of Taoist thought written and developed by other successors or fans, and added other materials Which is relevant to the theme of this study. For example, a source book related to Civil Society and the like.

The way of data analysis is adapted to the nature of philosophy and research objectives. There are four ways of analysis used in this research, namely: descriptive, hermeneutic, heuristic and synthesis. To achieve the objectives of the first study, using descriptive methods of hermeneutics. This method can interpret the meaning of a term or concept according to the way of Taoist philosophical thought, aims to reveal the meaning of thought in his teachings (Baker, Anton, 1984:23). Through a descriptive approach hermeneutics can obtain a general and comprehensive picture of the subject matter studied, namely the fundamental things that mean the importance of the ethical teachings of natural Taoism. To achieve the second research objective, heuristic methods are used. The heuristic approach is the critical step of finding a way to deal with a problem scientifically A path to science, through an explorative understanding of the meaning of a concept or text (Baker, Anton, $1996: 22)$. From this analysis can obtain specifications of the basic problems that arise in the empowerment of democratic societies towards civil society in Indonesia. To achieve the third research objective, a synthetic approach is used, which is eclectically compounded by drawing the nodes of logical and contextual relevance, the Taoist philosophical view of the relevant and contributive virtues of the basic problem 
in the empowerment of democratic societies to civil society in Indonesia.

\section{Result and Discussion}

\subsection{Basic things in the Taoist Natural Ethics}

The philosophy of Taoism is rooted in the historical experience of the Chinese people. Why does Taoism flourish in China, because its philosophical system rests on the roots of the problems of Chinese society itself, so that Taoist philosophy is integrated into the practice of everyday life. The birth of Taoism has to do with the historical experience of the destruction of the Chou kingdom as a result of the arbitrary abuse and action of the king in the administration. Human life is increasingly suffering and evil is rampant. From this historical experience some scholars have come to the conclusion that the rules made by humans can mislead the people, state legislation based on the brain or ratio will only harm the people. Humans must be willing to learn from the laws of nature that provide a lot of experience of human value of life, that is to be fair, pure chastity, discipline and obedience principles (Lasiyo, 1982 : 3-4 ).

3.2. Taoist nature ethics brings the Mission of Justice and Humanity

The historical experience gives the spirit for Taoism's journey to bring justice and humanity mission, that human life is ethically expected not to harm others, but to provide for the survival of others. Therefore the doctrine of virtue (te) is placed as the main theme in philosophical thought, then packaged in the natural ethical teachings of Taoism. The meaning of virtue according to Taoism as a moral character or strength that contains three elements: (1) Always make (to go), the tendency to give help to others, emerge from within a person is done continuously as a habit of life; (2) Contains a straightforward meaning, namely the tendency of attitude and behavior based on pure liver purity (original purity); (3) Meaning love say (heart). In virtue, the meaning of life is for one's neighbor, without distinction (Blakney, 1959:38). Virtue means the way of the Tao, to perfect happiness, or the happiness of the soul and the mind. The one who attains perfect happiness is one who has reached the level of the great man (sheng jen). Great Man lives for his neighbor and his environment.

3.3. The substance of the teachings of the Taoist Natural Ethics.

The natural ethical substance of Taoism lies in the question of the human way of life according to nature (the nature of Tao) to achieve the happiness of life, therefore human life must follow the Tao. Following Tao means conforming to the nature of the Tao. Taoism requires simplicity, sensitivity, flexibility, independence, cultivated, and joy for the good (Deng Ming Dao,1996:viii). These traits are manifested in Tao's way of life, that is; (1) living in accordance with the laws of nature; (2) living according to nature's nature; (3) and living naturally.

\subsubsection{Live according to the Law of Nature}

The substance of Taoist thought is an understanding of the principle of natural law that can be oriented into its ethical teachings, such as about the balance of life, working without speaking and sincere. The principle of life balance teaches that everything in this world is balanced or a polarized dualism. If perfect goodness and beauty have no harm or counterpart then it can not be known by man. The substance of 
the principle of balance is that life always evolves, all leading to one direction that is progress. The reality of life is all-round plural, but life takes place in harmony, and in harmony there is harmony in opposite (harmony in opposites). Interdependence in this life must be realized by human beings as objective reality, so that sense of justice and sincerity is always needed in life, therefore Taoism always recommends that people avoid extremes. The principle of working without speaking and being sincere to nature like a virtuous saint, giving lessons in silence only by example, in the Javanese language is said to be "lonely ing gamy" to describe sincere fair deeds. Nature works day and night with no speaking, sunrise and sunset, noon night change never heard his voice. Trees that bear fruit never feel possessed, but for anyone who likes them, not differentiate them for rich or poor, birds or bats. Humans are not aware of it because of limited awareness and thoughts. Moreover, the selfish man who thinks only something that benefits himself. Rarely are people who understand the meaning of sufficiency, they are too big to pursue a boundless desire. That is why there is a tendency of people corrupt, just articulate and acting pamrih.

\subsubsection{Live according to Natural Being} According to Taoism, every human being has its own natural nature. The path of each individual is his nature, his customs, and the laws of his development. All things are different from their nature, which is equally experienced is they are all equally happy if able to use the ability of his nature fully and freely. There is no absolute uniformity and there is no need for uniformity. Through understanding this natural way of life, Taoism wants to inculcate the attitude of human life in order to surrender completely so that it is not easy to complain in overcoming the difficulties of his life, because it must be realized that everything that happens is governed by natural law. In instilling an attitude. Surrender, Taoism teaches accept humiliation without complaint, accept misery as human nature.

\subsubsection{Living naturally}

The principle of fairness in Taoism contains the notion of a normative measure in the way people live everyday. Personality as seen from the outside is not important, what is important is the introduction of identity. Life naturally reflects the nature of water, that is soft and humble can always adjust to the circumstances. This is the nature of the weak and soft, but gets victory from the hard and strong. Understanding of life can naturally be interpreted as the process of recognition or discovery of identity. The norm of reasonableness is implied in a simple lifestyle, a humble and unconditional attitude. Through the understanding of a simple way of life, Taoism wants to inculcate the attitude of human life should not act excessively, human beings must release a false purity. Awareness of the need for a reasonable attitude of life also reflects the understanding of the need for metaphysical meaning of life, bahwasannya behind the life of this universe is a provision of natural laws that regulate it. Humans are only a part of the whole universe, therefore human life is limited, bound by other laws of nature and human beings are aware of life cycle. In order for man to achieve the happiness of his life, then the pattern of human life to adjust to the nature, such as simplicity, sincerity, fairness and obedience principle (Lim Tji Kay, 1991:22).

3.4. Contribute to the teaching of the Ethics of Natural Taoism 
Important points from the results of research that provide benefits as a contribution to civil society empowerment in Indonesia can be outlined as follows.

3.4.1. Harmony in the Plurality of Life

The essense of harmony for Taoism shows the existence of a state of existence in which there are elements of diversity that mutually support each other in harmony (harmonious co-exostence) and even harmony in opposite (harmony in opposites). In harmony each element fulfills the function in relation to the whole, and the whole will do good to its parts (Cooper, J.C, 1981:22). There are several principles of harmony that can answer the basic problem in the empowerment of civil society in Indonesia. The first principle, man in essence has its own nature, the way of life is to follow his nature. This doctrine reminds man to accept all the facts within himself by through various circumstances of his life, thus bringing the consequences that one must also realize the other person has also possessed and bound by his nature. Everyone knows the natural limits between each of them and therefore one should respect each other.

The existence of harmony is not a result of emotional responses but a universal necessity, as long as no harmony in human life fails and falls into the multiplicity space. In this kind of life people tend to deny rules (disobeyed). Yet human beings can still be accountable for as long as humans maintain the harmony of life according to the laws of nature and the yin-yang principle-which interplay and balance each other (Cooper, J.C, 1981). The rationale is important to consider as the question of plurality in civil society is not only a description of the diversity of social structures, but also about the dynamic process of social life that contains the substance of individual existential change, so that the empowerment of plurality requires a universal normative paradigm natural law of natu Based on the awareness of the founders of the state to prioritize the interests of the nation. The democratic spirit at that time was based on a high awareness of nationalism, so the question of plurality raises the values of solidarity, such as peer affection, mutual respect and mutual cooperation. The political elite has embedded in itself an understanding of the philosophical principle of unity and diversity or known as Bhinneka Tunggal Ika (Wertheim, W.F, 1959:147). It is now understandable that the growth of Indonesian nationhood is rooted in the question of the plurality of Indonesian society itself. It is not impossible that this nation now wants the growth of democracy through the empowerment of civil society. The third principle, each part fulfills the functions associated with the whole, and the whole will do good to the parts. The translation of this principle makes sense that life in nature is not without rules. Every part of the natural life has a function of its own life, but its existence is bound by the rules of the rest of life. So in fact this natural life is created in its harmonious form and arrangement, so that every part of the natural life can enjoy the peace and happiness of life or peace of mind and mind. If this issue is placed in the context of civil society empowerment then the concept of thinking is very important.

For in civil society it is more than just pro-democracy movements. Civility necessitates tolerance that is the willingness of individuals to accept different political views and social attitudes (Azyumardi Azra, 1994:7). 
HUMANIKA Vol.25 No.2 (2018)

ISSN 1412-9418

Tersedia online di http://ejournal.undip.ac.id/index.php/humanika

3.4.2. The Purity of the Heart in Democratic Lives

The doctrine of purity of heart is contained in the Taoist conception of the original Purity, the fact that should do not pursue profit, but do on the basis of the willingness of heart then will feel calm. Humans in the mini-style have a central position, namely as a mediator between the earth and the sky and in maintaining the balance between yin and yang. Failure in carrying out this task of life will fall into extremes and contradictions. All happiness and wisdom depends on the balance and harmony of this plurality. The sanctity of the heart for a person becomes very important in maintaining harmony and balance in the plurality of life. From a person's purity of heart will manifest social attitudes and behaviors that inclusively uphold democratic values.

\subsubsection{Living naturally in Political Culture}

Plurality and prevalence of social forces are part of a number of characters in civil society. In the plurality shows the diversity of elements of civil society life, such as religion, tradition, ethnicity, and political interest groups. Then there is the social aspect of social power, meaning that civil society can be described as a free public sphere as a precondition for the implementation of the whole political society capable of countering totalitarianism. Democratic or cultural ethics Politics does not want plurality as a source for the emergence of the egoism of interest groups that can interfere with the interests of the nation and state. The ethics of democracy prioritize norms for the achievement of interests in living together. Besides, democratic ethics will not take over the social forces to abolish the state, but it is precisely the social force that as a manifestation of the undercurrent movement is able to perform the function of offsetting the power of the state or the instrument of power control (Hikam, A.S, 1996:199).

Besides, democratic ethics will not take over the social forces to abolish the state, but it is precisely the social force that as a manifestation of the undercurrent movement is able to perform the function of offsetting the power of the state or the instrument of power control. Living naturally is like the nature of soft and humble water can adjust to the situation. Political culture will be more civilized if in its manifestation represent a way of life naturally. Ways of political decision-making are more democratic and maintain family values.

\section{Conclusion}

The natural ethical substance of Taoism lies in the question of human way of life according to nature (Tao's nature) to achieve the happiness of life. Taoism requires simplicity, caring for others, flexibility in addressing life issues, being independent, sharp in understanding, trained in life, and rejoicing in favor of kindness. The way of life Tao, that is living in accordance with the laws of nature, namely; Live according to natural traits and live accordingly. Live according to the laws of nature, for example; Fair, affection, life balance, work without speaking and sincerely. Living according to nature's nature, inculcating the attitude of human life in order to surrender completely so that it is not easy to complain in overcoming the difficulties of his life. Living naturally, reflecting the nature of water, that is soft and humble can always adjust to the circumstances. This is the nature of the weak and soft, but gets victory from the hard and strong. The basic problem in the empowerment of democratic society in Indonesia is the multicultural plurality of Indonesian society. The process of 
democratization often arises tensions, the friction of cross-group interests. Important matters of research results that benefit as a contribution to the empowerment of democratic civil society in Indonesia; Harmony in the plurality of life, the sanctity of the heart in democratic life, a natural life in politics.

The dynamics of democracy in Indonesia which carry the mission of freedom and participation, the elites and all components of society need to equip themselves with pure heart purity.

\section{References}

Azra. Azyumardi,1994. Menuju Masyarakat Madani (Gagasan Fakta dan Tantangan), PT. Remaja Rosdakarya Bandung Bakker, Anton. 1984. Metode-Metode Filsafat, Ghalia Indonesia, Jakarta ----------, 1996. Metodologi Penelitian Filsafat, Kanisius, Yogyakarta. Blakney, RB. 1955. The Way of Lao Tse, The New American Library of World Literature, Inc., Madison Avenue, New York.

Culla, Adi Suryadi. 1999. Masyarakat Madani (Pemikiran, Teori, dan Relevansi), PT. Gramedia Jakarta. Cooper, JC., 1981, Yin-Yang, The Taoist Harmony of Opposites, The Aquarian Press, Britain.

Deng Ming, Dao. 1966. Everyday Tao, Penguin Books, United Stated of America, Now York.

Fung Yu Lan, 1990. Sejarah Singkat Filsafat Cina, Terj : Soejono Soemargono Liberty, Yogyakarta. Hikam, Muhammad, AS, 1996. Demokrasi dan Civil Society, LP.3 ES., Jakarta.
Jenny Pearce. 1997. The Way of Taoism, Cambridge University Press, New York.

Kwee Tek Hoaij. 1935. Taoism and Ethics, Penguin Book, London.

Kwee Tek Hoaij, 1935. Taoism, Penguin Book, London.

Lasiyo, 1994. Seri Filsafat Cina, Taoisme, Fakultas Filsafat, UGM, Yogyakarta

Lim Tji Kay. 1991. Tao Te Ching, Macmillan Publishing Co., New York

Rosmini, 1996. Masyarakat Madani, Gramedia, Jakarta.

Wertheim, W.F, 1959. Indonesian Society in Transition, A.Manteau NV. Bussel

Wing Tsit Chan. 1963. The Way of Lao Tzu, Macmillan Publishing Co., New York. 
HUMANIKA Vol.25 No.2 (2018)

ISSN 1412-9418

Tersedia online di http://ejournal.undip.ac.id/index.php/humanika 